\title{
Geology
}

\section{Adakites from continental collision zones: Melting of thickened lower crust beneath southern Tibet}

Sun-Lin Chung, Dunyi Liu, Jianqing Ji, Mei-Fei Chu, Hao-Yang Lee, Da-Jen Wen, Ching-Hua Lo, Tung-Yi Lee, Qing Qian and Qi Zhang

Geology 2003;31;1021-1024

doi: $10.1130 / G 19796.1$

Email alerting services

click www.gsapubs.org/cgi/alerts to receive free e-mail alerts when new articles cite this article

Subscribe

Permission request click www.gsapubs.org/subscriptions/ to subscribe to Geology

click http://www.geosociety.org/pubs/copyrt.htm\#gsa to contact GSA

Copyright not claimed on content prepared wholly by U.S. government employees within scope of their employment. Individual scientists are hereby granted permission, without fees or further requests to GSA, to use a single figure, a single table, and/or a brief paragraph of text in subsequent works and to make unlimited copies of items in GSA's journals for noncommercial use in classrooms to further education and science. This file may not be posted to any Web site, but authors may post the abstracts only of their articles on their own or their organization's Web site providing the posting includes a reference to the article's full citation. GSA provides this and other forums for the presentation of diverse opinions and positions by scientists worldwide, regardless of their race, citizenship, gender, religion, or political viewpoint. Opinions presented in this publication do not reflect official positions of the Society.

\section{Notes}

Geological Society of America

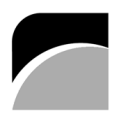

THE

GEOLOGICAL

SOCIETY

OF AMERICA 

lower crust beneath southern Tibet

\author{
Sun-Lin Chung* Department of Geosciences, National Taiwan University, Taipei, Taiwan \\ Dunyi Liu Institute of Geology, Chinese Academy of Geological Sciences, Beijing, China \\ Jianqing Ji School of Earth and Space Sciences, Peking University, Beijing, China \\ Mei-Fei Chu \\ Hao-Yang Lee \\ Da-Jen Wen \\ Department of Geosciences, National Taiwan University, Taipei, Taiwan \\ Ching-Hua Lo \\ Tung-Yi Lee Department of Earth Sciences, National Taiwan Normal University, Taipei, Taiwan \\ Qing Qian _hang ]- Institute of Geology and Geophysics, Chinese Academy of Sciences, Beijing, China
}

\begin{abstract}
Adakites are geochemically distinct intermediate to felsic lavas found exclusively in subduction zones. Here we report the first example of such magmas from southern Tibet in an active continental collision environment. The Tibetan adakites were emplaced from ca. 26 to $10 \mathrm{Ma}$, and their overall geochemical characteristics suggest an origin by melting of eclogites and/or garnet amphibolites in the lower part $(\geq \mathbf{5 0} \mathbf{~ k m})$ of thickened Tibetan crust. This lower-crustal melting required a significantly elevated geotherm, which we attribute to removal of the tectonically thickened lithospheric mantle in late Oligocene time. The identification of collisiontype adakites from southern Tibet lends new constraints to not only the Himalayan-Tibetan orogenesis-how and when the Indian lithosphere started underthrusting Asia can be depicted-but also the growth of the early continental crust on Earth that consists dominantly of the tonalite-trondhjemite-granodiorite suites marked by adakitic geochemical affinities.
\end{abstract}

Keywords: adakite, Tibet, continental collision, lower-crustal melting.

\section{INTRODUCTION}

Defant and Drummond (1990) proposed adakite to describe subduction-related volcanic and plutonic rocks of andesitic-dacitic to sodic rhyolitic compositions that exhibit geochemical characteristics suggesting an origin by partial melting of hydrated mafic source rocks in the form of eclogite or garnet amphibolite (Rapp et al., 1991; Martin, 1998). This melting may occur either in the basaltic crust of the downgoing oceanic slab (Defant and Drummond, 1990; Martin, 1998) or in the base of tectonically or magmatically thickened crust above the mantle wedge (Atherton and Petford, 1993; Kay and Kay, 1993). Adakites are widely regarded as the modern analogues of tonalite-trondhjemitegranodiorite (TTG) suites, the dominant component of many Archean terranes that shows geochemical similarities to adakites; these TTG suites, and hence Earth's early continental crust, are therefore often argued to have formed by melting of the subducting slabs (Martin, 1998; Foley et al., 2002). The argument appears to be consistent with most observations from Late Archean (3.0-2.5 Ga) terranes. However, geologic features such as large-scale $(>100 \mathrm{~km})$ linear trends, which are typically associated with modern-style subduction zones, are lacking in terranes older than 3.0 Ga (Abbott and Mooney, 1995; Zegers and van Keken, 2001).

This study deals with postcollisional magmas from southern Tibet, an active continental collision zone. Previous investigations, conducted only in areas west of Lhasa city, show that these magmas occurred as

\footnotetext{
*E-mail: sunlin@ntu.edu.tw.
}

small extrusive and intrusive bodies from ca. 25 to $10 \mathrm{Ma}$ (Coulon et al., 1986; Turner et al., 1996; Miller et al., 1999; Williams et al., 2001). The magmas can be divided into two major types, made up of ultrapotassic and calc-alkaline compositions, respectively. Whereas geochemical systematics of the ultrapotassic magmas suggest a phlogopitebearing peridotite source in the lithospheric mantle that has a complex, multistage enrichment history (Turner et al., 1996), the calc-alkaline ones consist solely of intermediate to felsic lithologies with petrochemical signatures indicative of a substantial crustal contribution in the petrogenesis (Miller et al., 1999; Williams et al., 2001). Here we report new outcrops of the second type of magmas from areas around Xigaze and east of Lhasa city. The ${ }^{40} \mathrm{Ar} /{ }^{39} \mathrm{Ar}$ and sensitive high-resolution ion microprobe (SHRIMP) U-Pb zircon dating results indicate that these magmas formed between ca. 26 and $13 \mathrm{Ma}$, affirming a widespread occurrence of the postcollisional magmatism that extends for a distance of $\sim 1500 \mathrm{~km}$ across southern Tibet. Our geochemical data furthermore suggest the magmas to be comparable to adakite from modern subduction zones. Thus, they are argued to represent the first example of adakites identified from the modern continental collision settings, and provide new information about the Himalayan-Tibetan orogenesis as well as the growth of the early continental crust on Earth.

\section{BACKGROUND AND ANALYTICAL RESULTS}

The collision of India with Asia starting in early Cenozoic time resulted in the Himalayan-Tibetan orogen, which is the most outstanding natural laboratory for studying continental orogenic processes, and has attracted numerous investigations (Yin and Harrison, 2000, for a review). Before the collision, the northward subduction of the Neotethyan slab along the southern margin of the Asian continent gave rise to an Andean-type magmatic arc, manifested by the voluminous Gangdese batholith and Linzizong volcanic successions now exposed in the Lhasa terrane of southern Tibet (Fig. 1). These magmas, having typically calc-alkaline compositions, were mainly emplaced from Cretaceous to Eocene (ca. 120-40 Ma) time, before postcollisional magmatism was active on this part of the Tibetan Plateau (Turner et al., 1996; Chung et al., 1998; Miller et al., 1999; Williams et al., 2001). Magmas of the later stage are generally potassium rich and have geochemical signatures reflective of a dominant source in the enriched subcontinental lithospheric mantle, implying a prominent geothermal perturbation and involvement of the Tibetan deep lithosphere in the melt generation. Among various geodynamic processes proposed, removal of the lower portion of collision-thickened lithospheric mantle under Tibet has been widely accepted as the cause of the magmatism (cf. Turner et al., 1996).

The magmatic rocks we investigated crop out either as dike swarms or small-volume plugs that crosscut or intrude the Gangdese 
Figure 1. Simplified geologic map showing outcrops of magmatic rocks in southern Tibet made essentially of Lhasa terrane. Inset denotes $\mathrm{Ce}$ nozoic tectonic framework and block extrusion in East Asia related to India-Asia collision. BNSBangong-Nujiang suture; ITS-Indus-Tsangpo suture; MCT-Main Central thrust; STDS-South Tibet detachment system.

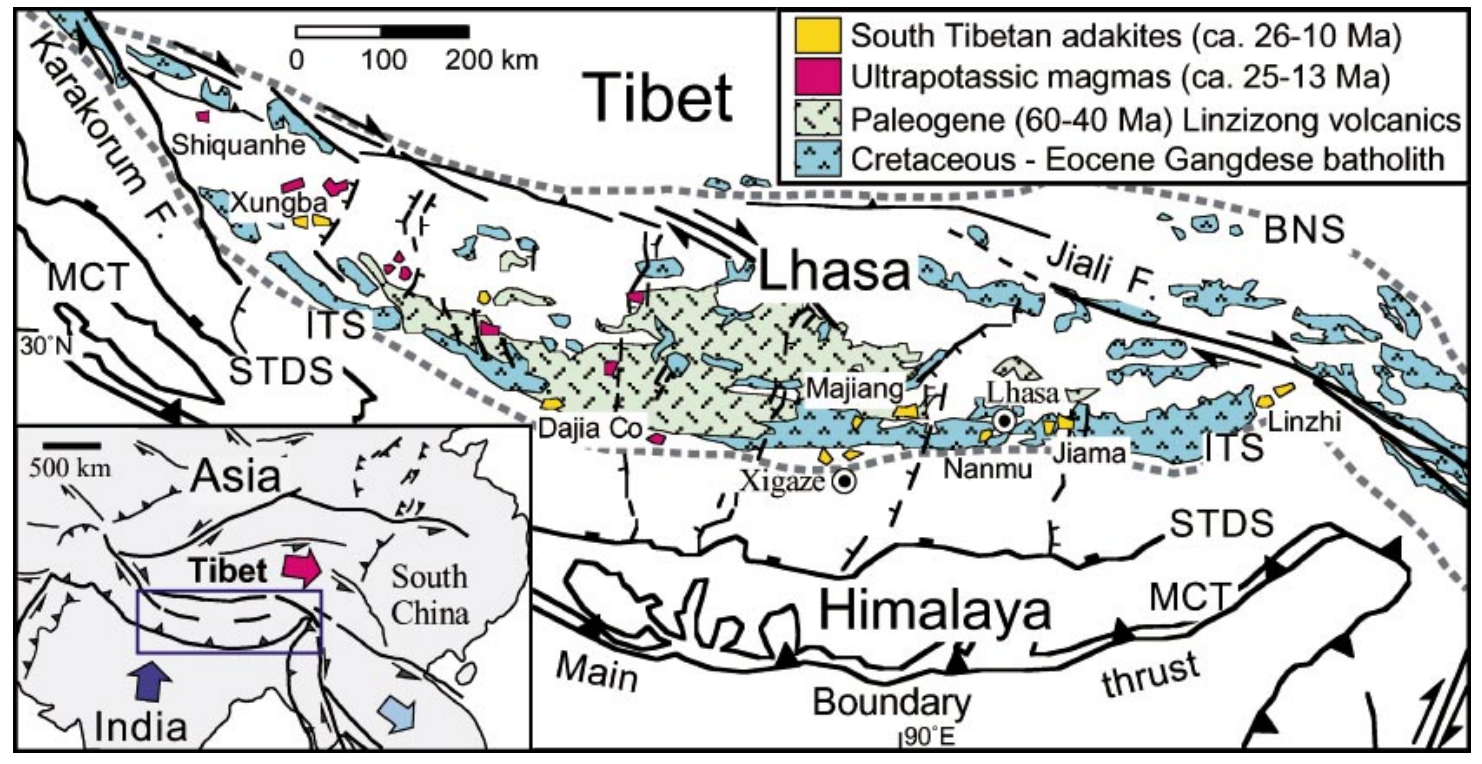

batholith, Linzizong volcanic rocks, and/or underlying metasedimentary formations. These magmatic rocks include dikes from areas in the north of Xigaze and south of Majiang and dikes or plugs from areas around Nanmu, Jiama, and Linzhi (Fig. 1): the former generally exhibit fine-grained texture, whereas the latter are marked by abundant phenocrysts of sanidine along with porphyritic to holocrystalline texture. The latter type of rocks, referred to as "granitic porphyry" by local workers, contains copper and subordinate molybdenum-gold deposits in localities. Three samples of this type, two from Jiama (ET023 and ET025B) and one from Linzhi (T016), were subjected to single-zircon $\mathrm{U}-\mathrm{Pb}$ dating by using the SHRIMP II at the Chinese Academy of Geological Sciences, Beijing, which yielded weighted means of ${ }^{206} \mathrm{~Pb} /{ }^{238} \mathrm{U}$ ages of $17.0 \pm 0.5(2 \sigma), 15.0 \pm 0.4$, and $26.2 \pm 0.6 \mathrm{Ma}$, respectively (Appendix $1^{1}$ ). Sanidine separates from ET025B were subjected to ${ }^{40} \mathrm{Ar} /{ }^{39} \mathrm{Ar}$ dating at the National Taiwan University, Taipei, giving a consistent plateau age of $15.2 \pm 0.4 \mathrm{Ma}(2 \sigma)$. The latter method was

${ }^{1}$ GSA Data Repository item 2003149, Appendices 1-3, zircon U-Pb dating, Ar-Ar dating, and major and trace element data, is available online at www.geosociety.org/pubs/ft2003.htm, or on request from editing@geosociety. org or Documents Secretary, GSA, P.O. Box 9140, Boulder, CO 80301-9140, USA.

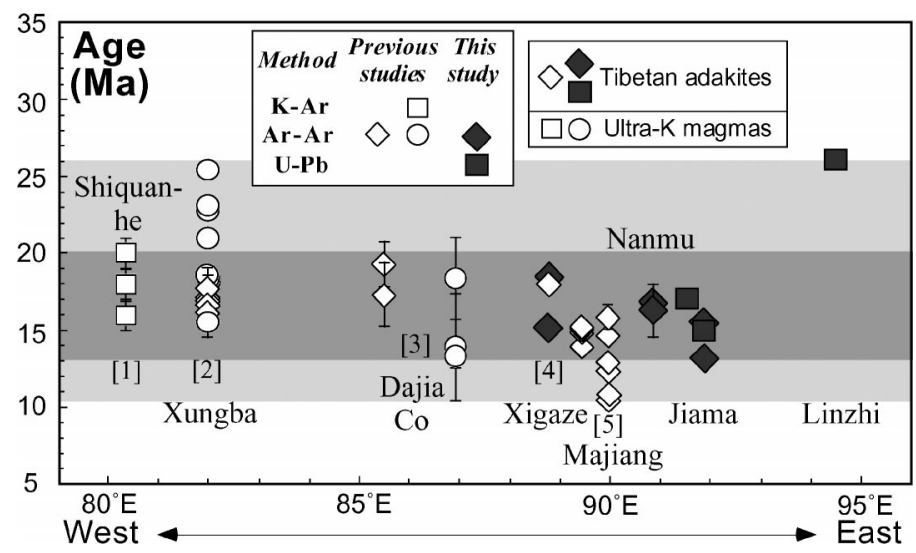

Figure 2. Age vs. Iongitudinal distribution of postcollisional magmas from Lhasa terrane, southern Tibet. Literature sources of age data include 1-Shiquanhe (Turner et al., 1996), 2-Xungba (Miller et al., 1999), 3-Dajia Co (Williams et al., 2001), 4-Xigaze (Yin and Harrison, 2000; Spicer et al., 2003), and 5-Majiang (Coulon et al., 1986). Analytical errors $(2 \sigma)$ are shown when larger than symbols. applied to date additional samples from Jiama (ET025E), Nanmu (ET026C and ET026D), and Xigaze (T041D and T081), yielding ${ }^{40} \mathrm{Ar} /$ ${ }^{39}$ Ar plateau ages of $13.2 \pm 0.4,16.6 \pm 0.4,16.4 \pm 1.8,15.0 \pm 0.6$, and $18.4 \pm 0.8 \mathrm{Ma}$, respectively (Appendix 2; see footnote 1). Together with literature data, these results (Fig. 2) delineate a late Oligocene to middle Miocene duration (ca. 26-10 Ma) and an obviously more widespread occurrence than had been recognized for the postcollisional magmatism from southern Tibet. Relative to the second type of magmas, which extend over an $\sim 1300 \mathrm{~km}$ distance from Xungba to Linzhi (Fig. 1), the first type-ultrapotassic magmas-appears to be confined to the western localities. More investigations, particularly in the eastern and northern Lhasa terrane, are needed for better understanding the distribution of the postcollisional magmatism.

Our major and trace element results (Appendix 3; see footnote 1) led to a new finding that the second type of the southern Tibetan magmas, previously referred to as "calc-alkaline lavas" (Miller et al., 1999; Williams et al., 2001), have geochemical characteristics similar to those of modern adakites (Fig. 3A). This suite of magmas consists of intermediate to felsic compositions $\left(\mathrm{SiO}_{2}\right.$ contents ranging from $\sim 57$ to 73 wt $\%$ and $\mathrm{Al}_{2} \mathrm{O}_{3}$ contents ranging from $\sim 15$ to $19 \mathrm{wt} \%$ ), lacks a mafic member, and is generally sodium rich, although potassium-rich varieties are observed in the Jiama area. The magmas are further marked by high $\mathrm{Sr}$ (to $\sim 1100 \mathrm{ppm}$ ), low $\mathrm{Y}$ ( $<10 \mathrm{ppm}$ ), and strongly fractionated rare earth element patterns (Fig. 3A), mimicking adakites from the circum-Pacific subduction zones (Defant and Drummond, 1990; Martin, 1998), but distinctly different from the Paleogene (ca. 60-40 Ma) Linzizong volcanic rocks. They exhibit elevated $\mathrm{La} / \mathrm{Yb}$ and $\mathrm{Sr} / \mathrm{Y}$ ratios that are discriminating features of the adakitic magmas (Fig. 3B), suggesting an origin by melting of a mafic source in which garnet and/ or amphibole are residual phases (cf. Rapp et al., 1991). These Tibetan "adakites" can be divided into two groups on the basis of Sr contents, i.e., a more abundant high-Sr group $(\mathrm{Sr}=1100-690 \mathrm{ppm})$ and a subordinate low-Sr group $(\mathrm{Sr}<400 \mathrm{ppm})$. The latter, recovered so far only from the Jiama area, is made up essentially of potassic lithologies that have lower $\mathrm{Al}_{2} \mathrm{O}_{3}$ contents $(<16 \mathrm{wt} \%$; Appendix 3 [see footnote $1]$ ). These two groups may be explained by the absence or presence, respectively, of residual plagioclase in the source.

\section{MAGMA GENESIS AND TECTONIC SIGNIFICANCE}

A direct inference derived from the occurrence of adakitic magmas in southern Tibet is that the lower part ( $\geq 50 \mathrm{~km}$ ) (Rapp et al., 1991 ) of the thickened Tibetan crust (now as thick as $\sim 70-80 \mathrm{~km}$ ) 


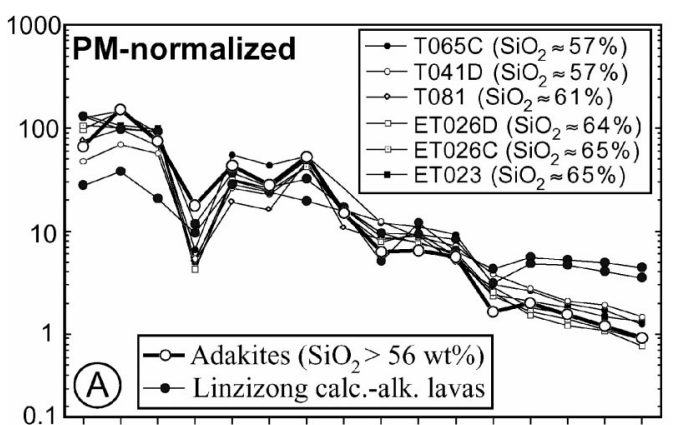

$\mathrm{Rb}$ Ba K NbLaCe SrNd P Zr Eu Ti Dy Y Er Yb

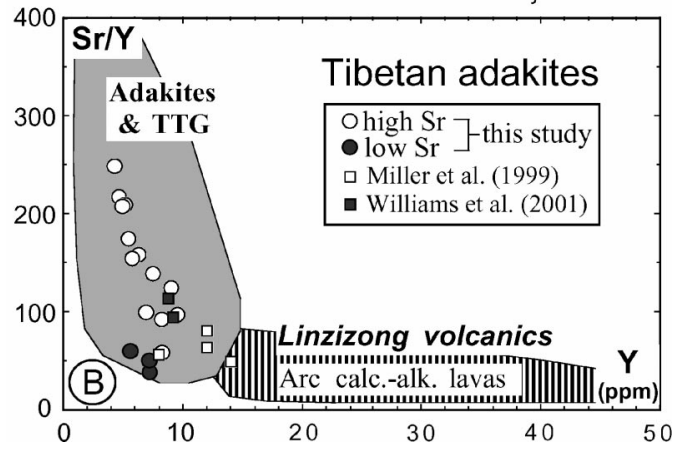

Figure 3. A: Primitive mantle (PM)-normalized element-variation diagram. B: $\mathrm{Sr} / \mathbf{Y}$ vs. Y. Data for average adakite and fields of adakites, tonalitetrondhjemite-granodiorite (TTG), and island-arc calc-alkaline lavas are from Defant and Drummond (1990) and Martin (1998), and Linzizong volcanic rocks are from Lee et al. (2003).

(Owens and Zandt, 1997) is composed of eclogites and/or garnet amphibolites, i.e., metamorphosed mafic rocks that have been yet exposed at the surface but whose presence is predicted by seismic experiments (Yuan et al., 1997) and thermal modeling (Le Pichon et al., 1997). Fluids are generally thought to be the key element in the process of eclogitization of the crustal roots in collisional orogens (cf. Leech, 2001). Beneath southern Tibet, a "wet" environment capable of driving eclogitization of the lower part of thickened crust is assumed because the protracted Neotethyan subduction would have released significant amounts of water via slab dehydration reactions. There are two reasons that would preclude the subducted Neotethyan oceanic crust from behaving as a potential source of the Tibetan adakites: (1) these adakites show radiogenically enriched neodymium and strontium isotope compositions (Turner et al., 1996; Miller et al., 1999; Williams et al., 2001) that clearly suggest an origin by melting of continental rather than oceanic crust material, and (2) the Neotethyan slab is more likely to have become detached from the orogenic system and then to have sunk into the deep mantle in Eocene time (Kohn and Parkinson, 2002; DeCelles et al., 2002). Adopting the foregoing scenarios, we may explore the following four relevant issues: (1) What mechanisms are responsible for the crustal thickening in southern Tibet? (2) When did the crust achieve the thickness to become eclogitized in its lower part? (3) How was the eclogitized lower crust heated up to melt? (4) Why did the adakitic magmatism cease ca. 10 Ma?

Two catastrophic postcollisional geodynamic events have been proposed in southern Tibet, the breakoff of the Tethyan subducting slab ca. 45 Ma (Kohn and Parkinson, 2002) and the delamination of the thickened Lhasa lithospheric root ca. 25 Ma (Miller et al., 1999; Williams et al., 2001). The slab breakoff, which prevented the onceattached Indian continental lithosphere from further subduction because of loss of slab pull, would have led to the cessation of the GangdeseLinzizong magmatism, rapid exhumation of the Greater Himalayan rocks, and sudden rise of the orogen, although since Cretaceous time a high but narrow mountain range similar to the present AltiplanoPuna Plateau of the central Andes may have existed in what is now southern Tibetan (Fielding, 1996). Exemplified by the Andean analoguewhere a correlation between lava geochemistry and crustal thickness has been clearly documented (Kay and Kay, 1993, 2002) - the calcalkaline nature and high contents of $\mathrm{Y}$ and heavy rare earth elements observed in the Linzizong volcanic rocks (Fig. 3) imply a magmatic origin from the mantle wedge with a normal (e.g., 30-35 km) crustal thickness. If this is the case, a drastic thickening of the Lhasa lithosphere, mostly within its lower crust and mantle (Fielding, 1996), must have happened between the waning of the Linzizong volcanism (ca. $40 \mathrm{Ma}$ ) and the beginning of the adakitic magmatism (ca. $26 \mathrm{Ma}$ ). For the Lhasa lithosphere to have been thickened to as much as $\sim 300 \mathrm{~km}$ (Fielding, 1996) is considered possible only if the Indian cratonic lithospheric mantle is older, and so less dense and intrinsically more buoyant, than the Lhasa lithospheric mantle. Therefore, after loss of the Neotethyan slab pull ca. $45 \mathrm{Ma}$, the continuous northward impingement of the Indian block gave its buoyant lithospheric mantle nowhere to go, but gave rise to a tremendous magnitude of contraction and thickening in the deeper part of the Lhasa lithosphere.

The presumed wet condition in the tectonically thickened Lhasa lithosphere would have facilitated eclogitization of its crustal root; some part of which that did not complete the metamorphic reaction may have become partially eclogitized amphibolites or related rocks (Leech, 2001). A following question is, how were such crustal rocks melted? In southern Tibet, consisting essentially of the Lhasa terrane that separates from central-northern Tibet by the Bangong-Nujiang suture (Fig. 1), we follow previous workers (Turner et al., 1996; Chung et al., 1998; Miller et al., 1999; Williams et al., 2001) to argue delamination, or "convective removal" in a more strict sense, of the base of the thickened lithosphere for the magma generation. Under the framework of this hypothesis, the spatially and temporally associated adakites and ultrapotassic rocks are interpreted to be melts of the eclogitized lower crust and enriched domains in the remnant lithospheric mantle, respectively, caused by a significant geothermal perturbation owing to removal of the Lhasa lithospheric root. The onset of the magmatism, i.e., ca. $26 \mathrm{Ma}$ for adakites from Linzhi in the east and ca. $25 \mathrm{Ma}$ for ultrapotassic lavas from Xungba in the west (Fig. 2), should coincide with or slightly postdate the delamination (cf. Williams et al., 2001). This interpretation suggests that the lithospheric root was delaminated in the late Oligocene. Beneath the eastern Lhasa terrane, the lithospheric mantle may have been removed almost completely; hence there were no ultrapotassic but only adakitic magmas generated in the region. This argument for a massive or even complete loss of the lithospheric mantle in southern Tibet is consistent with geologic observations (Fielding, 1996) and seismic imaging results (Owens and Zandt, 1997). Without any lower-crustal or mantle rocks exposed at the surface and/ or captured as xenoliths by the magmas, the delamination-caused elevated geothermal gradient can not be precisely estimated. It may have approximated the xenolith-derived geotherm proposed for the Qiangtang terrane of central Tibet (Hacker et al., 2000), an estimation that is in general agreement with the requirement of $\geq 50 \mathrm{~km}$ depth (Rapp et al., 1991; Kay and Kay, 2002) for producing adakitic melts in the eclogitized lower crust.

The removal of the Lhasa lithospheric root, given a maximum estimate of $\sim 300 \mathrm{~km}$ for the lithospheric thickness before delamination (Fielding, 1996), was gigantic and must have played a crucial role in the formation of the southern Tibetan Plateau. This removal event, moreover, created space that would have allowed the buoyant Indian lithospheric mantle to move northward and begin underthrusting Asia (Owens and Zandt, 1997). The northward underthrusting of the cold Indian mantle lithosphere may have had two major effects regarding the Tibetan tectonomagmatic evolution: (1) it would have gradually 
shut off the heat from the asthenosphere and eventually terminated the delamination-induced magmatism ca. 13-10 Ma (Fig. 2); and (2) it provides support that holds up the high and flat topography of southern Tibet (Fielding, 1996; Owens and Zandt, 1997). Therefore, although the southern plateau should have attained its maximum sustainable elevation and begun to collapse gravitationally in the context of the delamination hypothesis, a quasi-steady state seems to have been reached so that the altitude of this region has remained unchanged over the past $\sim 15$ m.y. (Spicer et al., 2003). This stability is unlikely to have been a consequence of any single geodynamic event, but requires potential-energy dissipation processes - such as gravitational collapse, block extrusion, and lower-crustal flow, which occurred in and/or around the Tibetan Plateau (see DeCelles et al., 2002, for review) - to have been continuously balanced by the support from the underthrust Indian lithosphere since at least middle Miocene time.

\section{BROADER IMPLICATIONS}

The identification of modern adakites from the active collision zone, southern Tibet, has implications for growth of Earth's early continental crust. As an alternative to the subduction-based hypothesis (Martin, 1998), a scenario that involves collision followed by delamination of a thickened lithospheric keel appears to match with many observations and interpretations derived from the Archean terranes. In the Early Archean, with a hotter heat-flow condition, the protocrust was more likely to have had a structure similar to that of present-day large oceanic igneous plateaus (Abbott and Mooney, 1995). Thus, much of the formation and stabilization of the early continental crust may have been achieved by recurrent accretions of oceanic plateaulike crust, which was too thick to be subducted as a single unit (Abbott and Mooney, 1995). Such relatively unsubductable oceanic plateaus could have been accreted to deeper crustal levels and then melted to produce the TTG magmas once a sufficiently thick eclogite layer had formed at the base of the crust and delaminated owing to its high density (Zegers and van Keken, 2001). In this sense, the TTG suites would have originated from the middle crust composed essentially of garnet amphibolites, rather than eclogites, consistent with the recent experimental work (Foley et al., 2002). Partial melting in the deep part, but not the base, of an oceanic plateau-type protocrust following terrane accretion and delamination should have been pivotal in the Early Archean crustal evolution, in contrast to what happened in the Late Archean, when subduction of the entire oceanic lithosphere began and melting in the subducting oceanic crust to form the TTG magmas became dominant (Foley et al., 2003). Our new findings from southern Tibet not only demonstrate the first example of occurrence of collisiontype adakites, but also reveal a uniformitarian link between the ancient and modern Earth. The latter points to the necessity of reevaluating the importance of terrane collision and accretion, relative to subduction, in the generation of adakitic and TTG magmas, and the continental crust, through geologic time.

\section{ACKNOWLEDGMENTS}

We thank H.-M. Li, B. Song, and H. Tao for help with zircon dating experiments, and Bob Kay and Richard Arculus for insightful reviews. This work benefited from support by the National Science Council, Taiwan.

\section{REFERENCES CITED}

Abbott, D.H., and Mooney, W., 1995, The structural and geochemical evolution of the continental crust: Support for the oceanic plateau model of continental growth: Review of Geophysics, Supplement, p. 231-242.

Atherton, M.P., and Petford, N., 1993, Generation of sodium-rich magmas from newly underplated basaltic crust: Nature, v. 362, p. 144-146.

Chung, S.-L., Lo, C.-H., Lee, T.-Y., Zhang, Y., Xie, Y., Li, X., Wang, K.-L., and Wang, P.-L., 1998, Diachronous uplift of the Tibetan Plateau starting 40 Myr ago: Nature, v. 394, p. 769-773.

Coulon, C., Maluski, H., Bollinger, C., and Wang, S., 1986, Mesozoic and Cenozoic volcanic rocks from central and southern Tibet: ${ }^{40} \mathrm{Ar} /{ }^{39} \mathrm{Ar}$ dating, petrological characteristics and geodynamic implications: Earth and Planetary Science Letters, v. 79, p. 281-302.

DeCelles, P.G., Robinson, D.M., and Zandt, G., 2002, Implications of shortening in the Himalayan fold-thrust belt for uplift of the Tibetan Plateau: Tectonics, v. 21, no. 6, 1062, DOI: 10.1029/2001TC001322.

Defant, M.J., and Drummond, M.S., 1990, Derivation of some modern arc magmas by melting of young subducted lithosphere: Nature, v. 347 p. $662-665$.

Fielding, E.J., 1996, Tibetan uplift and erosion: Tectonophysics, v. 260, p. $55-84$.

Foley, S., Tiepolo, M., and Vannucci, R., 2002, Growth of early continental crust controlled by melting of amphibolite in subduction zones: Nature, v. 417 , p. 837-840.

Foley, S.F., Buhre, S., and Jacob, D.E., 2003, Evolution of the Archaean crust by delamination and shallow subduction: Nature, v. 421, p. 249-252.

Hacker, B.R., Gnos, E., Ratschbacher, L., Grove, M., McWilliams, M., Sobolev, S.V., Jiang, W., and Wu, Z., 2000, Hot and dry deep crustal xenoliths from Tibet: Science, v. 287, p. 2463-2466.

Kay, R.W., and Kay, S.M., 1993, Delamination and delamination magmatism: Tectonophysics, v. 217, p. 177-189.

Kay, R.W., and Kay, S.M., 2002, Andean adakites: Three ways to make them: Acta Petrologica Sinica, v. 18, p. 303-311.

Kohn, M., and Parkinson, C.D., 2002, Petrologic case for Eocene slab breakoff during the Indo-Asian collision: Geology, v. 30, p. 591-594.

Lee, H.-Y., Chung, S.-L., Wen, D.-J., Ji, J., Qian, Q., Lo, C.-H., and Lee, T.Y., 2003, Age and geochemical constraints on the genesis of the Paleogene Linzizong volcanic successions in southern Tibet: Geophysical Research Abstracts, v. 5, p. 6426.

Leech, M.L., 2001, Arrested orogenic development: Eclogitization, delamination and tectonic collapse: Earth and Planetary Science Letters, v. 185, p. 149-159.

Le Pichon, X., Henry, P., and Goffé, B., 1997, Uplift of Tibet from eclogites to granulites-Implications for the Andean plateau and the Variscan belt: Tectonophysics, v. 273, p. 57-76.

Martin, H., 1998, Adakitic magmas: Modern analogues of Archaean granitoids: Lithos, v. 46, p. 411-429.

Miller, C., Schuster, R., Klötzli, U., Frank, W., and Purtscheller, F., 1999, Postcollisional potassic and ultrapotassic magmatism in southwest Tibet: Geochemical and $\mathrm{Sr}-\mathrm{Nd}-\mathrm{Pb}-\mathrm{O}$ isotopic constraints for mantle source characteristics and petrogenesis: Journal of Petrology, v. 40, p. 1399-1424.

Owens, T.J., and Zandt, G., 1997, Implications of crustal property variations for models of Tibetan Plateau evolution: Nature, v. 387, p. 37-43.

Rapp, R.P., Watson, E.B., and Miller, C.F., 1991, Partial melting of amphibolite/ eclogite and the origin of Archean trondhjemites and tonalites: Precambrian Research, v. 51, p. 1-25.

Spicer, R.A., Harris, N., Widdowson, M., Herman, A.B., Guo, S., Valdes, P.J., Wolfe, J.A., and Kelley, S., 2003, Constant elevation of southern Tibet over the past 15 million years: Nature, v. 421, p. 622-624.

Turner, S., Arnaud, N., Liu, J., Rogers, N., Hawkesworth, C., Harris, N., Kelley, S., van Calsteren, P., and Deng, W., 1996, Postcollision, shoshonitic volcanism on the Tibetan Plateau: Implications for convective thinning of the lithosphere and the source of ocean island basalts: Journal of Petrology, v. 37, p. 45-71.

Williams, H., Turner, S., Kelley, S., and Harris, N., 2001, Age and composition of dikes in southern Tibet: New constraints on the timing of east-west extension and its relationship to postcollisional magmatism: Geology, v. 29 , p. $339-342$.

Yin, A., and Harrison, T.M., 2000, Geologic evolution of the Himalayan-Tibetan orogen: Annual Review of Earth and Planetary Sciences, v. 28, p. 211-280.

Yuan, X., Ni, J., Kind, R., Mechie, J., and Sandvol, E., 1997, Lithospheric and upper mantle structure of southern Tibet from a seismological passive source experiment: Journal of Geophysical Research, v. 102 , p. 27,491-27,500.

Zegers, T.E., and van Keken, P.E., 2001, Middle Archean continental formation by crustal delamination: Geology, v. 29, p. 1083-1086.

Manuscript received 9 May 2003

Revised manuscript received 31 July 2003

Manuscript accepted 1 August 2003

Printed in USA 